\title{
Development of a method of synthesis of trimethyl ester of phosphonacetic acid
}

\author{
(C) Leonid V. Kovalenko, ${ }^{*}$ Antonida V. Kalistratova, Maxim S. Oshchepkov, ${ }^{+}$Ivan S. Kuzmin, \\ Anna G. Polivanova, Sergey V. Tkachenko, Inna N. Solovieva, and Eugenia V. Sokruta \\ D. Mendeleev University of Chemical Technology of Russia. Miusskaya Sq. 9. \\ Moscow, 125047.Russia.Phone:+7 (495)495-24-15.E-mail: maxim.os@mail.ru
}

\begin{abstract}
*Supervising author; ${ }^{+}$Corresponding author
Keywords: phosphonacetic acid, interphase catalysis, dimethylphosphite, chloroacetate.
\end{abstract}

\section{Abstract}

In the recent years the methods of synthesis and biological activity of phosphorus-containing analogues of biogenic carboxylic acids that are potential anti-metabolites of corresponding endogenous ligands in metabolic processes have been intensively studied.

Phosphonacetic (PAA) and phosphonformic acids are the most important biological active phosphoruscontaining carboxylic acids. Antiviral activity of phosphonacetic acid and some it's derivates via inhibition of replication of viral DNA is proven by a number of studies, but searching of efficient and economical method of synthesis of PAA for industrial manufacturing still going on.

In this paper, development of the method of synthesis of trimethyl ester of PAA that is the most convenient initial compound for further PAA synthesis is considered. The basis of this development was taken the reaction of interphase alkylation of dimethylphophite by methylchloroacetate without any solvents. Potassium carbonate or sodium carbonate in presence of appropriate phase transfer catalyst was used as a base in this reaction. In the course of the work, the kinetics and selectivity of this reaction were investigated using different bases and the corresponding kinetic curves were obtained. In case of sodium carbonate as a base the effect of using different phase transfer catalysts on yield and selectivity of this reaction was shown. As part of the study, a series of experiments were carried out and optimal process conditions were determined that allow it to be scaled using commercially available substrates and without the use of labor-intensive and high-cost technological methods.

\section{References}

[1] Arunava Roy, Ansari Ahmed Mairaj, Kumar Binod. Interferon- $\gamma$-inducible protein 16 (IFI16) is required for the maintenance of Epstein- Barr virus latency. Virology Journal. 2017. 14:221. P.1-12.

[2] Danielle E. Lyons, Kuan-Ping Yu, Jason A. Vander Heiden. Mutant cellular AP-1 proteins promote expression of a subset of Epstein-Barr virus late genes in the absence of lytic viral DNA replication. $J$. of Virology. 2018. Vol.92. P.19-85.

[3] J.C.H. Mao et al. Structure-activity studies on phosphonoacetate. Antimicrob. Agents Chemother. 1985. Vol.27. No.2. P.197-202.

[4] V.M. Balyshev et al. Production of typical haemadsorption-inhibiting reference serums for the African swine fever virus. Legal regulation aspects in veterinary. 2015. No.2. P.23-25. (russian)

[5] J.H. Hay, I.H. Subar-Sharpe. Mutants of herpes simplex virus types 1 and 2 that are resistant to phosphonoacetic acid induce altered DNA polymerase activities in infected cells J. Gen. Virol. 1976. Vol.31. No.1. P.145-148.

[6] E. Helgstrand, H. Flodh, J.O. Lernestedt. Developments in antiviral therapy. J. Oxford. London. Acad. Press. 1980. P.63.

[7] L. Dajiang, F. Wenmin, S. Sankar. Continuous DNA replication is required for late gene transcription and maintenance of replication compartments in gammaherpesviruses. PLoS pathogens. 2018. Vol.14. No.5. P.1-25.

[8] M.M. Zubairov et al. Antiviral and therapeutic effects of phosphonoacetic acid and its derivatives. Chemical safety. 2017. Vol.1. No.1. P.146-157. (russian)

[9] T.I. Stepanova et al. The use of CALS scientific research data systems for obtaining trimethyl phosphonacetate. Chemical industry today. 2013. No.3. P.45-50. (russian) 
[10] A. Mikalkenas, B. Ravoityte, D. Tauraite, E. Serviene. Conjugation of phosphonoacetic acid to nucleobase promotes a mechanism-based inhibition. J. of Enzyme Inhibition and Medicinal Chemistry. 2018. Vol.33. No.1. P.384-389.

[11] E.V. Socruta, V.A. Kalistratova, L.V. Kovalenko. Trimethyl phosphonacetate hydrolysis intensification. Achievements in chemistry and chemical technology. 2017. Vol.31. No.12 (193). P.30-32. (russian)

[12] V.A. Garibina, A.V. Dogadina, B.I. Ionin and A.A. Petrov. A method of obtaining S-alkyl esters of phosphonoacetic acids. 1988. Patent SU 1353779, C07F 9/40. (russian)

[13] N.A. Bondarenko, A.V. Harlamov and M.V. Rudomino. A method of obtaining trimethyl ester of phosphonoacetic acid. 2013. Patent RU 2527977Cl C07F 9/40. (russian)

[14] L.P. Santo et al. A new method of obtaining phosphonoacetic acid. Achievements in chemistry and chemical technology. 2016. Vol.30. No.11(180). P.74-76. (russian)

[15] L.V. Kovalenko, V.A. Kalistratova, , S.V. Tkachenko, M.S. Oshchepkov, I.S. Kuzmin, I.N. Solovieva, E.V. Socruta and G.A. Toporkov. A method of obtaining trialkyl esters of phosphonoacetic acid. 2019. Patent RU 2678096 C07F 9/40. (russian) 